\title{
Effect of Organic Manures and Amendments on Quality Attributes and Shelf Life of Banana cv. Grand Naine
}

\author{
Vanilarasu $\mathrm{K}^{1^{*}}$ and Balakrishnamurthy $\mathbf{G}^{2}$ \\ ${ }^{1}$ Ph. D. Scholar (Horticulture) in Fruit Science, Department of Fruit Crops, Tamil Nadu Agricultural University, \\ Coimbatore - 641 003, Tamil Nadu, India \\ ${ }^{2}$ Professor (Horticulture), in Fruit Science, Department of Fruit Crops, Tamil Nadu Agricultural University, \\ Coimbatore - 641 003, Tamil Nadu, India
}

*Corresponding author: Vanilarasu K, Ph. D. Scholar (Horticulture) in Fruit Science, Department of Fruit Crops, Tamil Nadu Agricultural University, Coimbatore - 641 003, Tamil Nadu, India, Tel: +919500627373; E-mail: arasuvani88@gmail.com

Rec date: Mar 05, 2014; Acc date: Apr 20, 2014; Pub date: Apr 22, 2014

Copyright: @2014 Vanilarasu K, et al. This is an open-access article distributed under the terms of the Creative Commons Attribution License, which permits unrestricted use, distribution, and reproduction in any medium, provided the original author and source are credited.

\begin{abstract}
Of late growing awareness on health makes consumer more concerned for food quality and safety. In banana Total soluble solids, acidity and sugar content mostly determine the degree of acceptability of fruit. An experiment was conducted during 2010-11 with 12 different treatment combinations of Farmyard manure, Vermicompost, Neem cake, Wood ash and green manures (organic sources) along with and without microbial inoculants (Arbuscular mycorrhizae, Azospirllium, Phosphate solubilising bacteria and Trichoderma harzianum) comparison with inorganic sources alone on quality attributes and shelf life of banana cv. Grand Naine (AAA). Results revealed that the treatment T10 (Farmyard manure @ 10 kg + Neem cake@1.25 kg + Vermicompost @ 5 kg and Wood ash @ 1.75 $\mathrm{kg}$ /plant + Triple green manuring with sunhemp + Double intercropping of Cow pea + biofertilizers viz., Vesicular Arbuscular Mycorrhizae @ 25 g, Azospirillum @ 50 g, Phosphate solubilizing bacteria @ 50 g and Trichoderma harzianum @ 50 g/plant) registered the maximum quality attributes (TSS - $23.23 \%$, Acidity - $0.82 \%$, Ascorbic acid $12.92 \mathrm{mg}$. $100 \mathrm{~g} \mathrm{-1}$, Non-reducing and Total sugars - 6.06 and $14.92 \%$ ) besides enhancing the shelf life of banana (14.03 days) and reduced physiological loss in weight $(7.44 \%)$.
\end{abstract}

Keywords: Green manures; Organic manures; Bio-fertilizers; Inorganic fertilizers; Quality and shelf life

\section{Introduction}

Banana (Musa sps.) is the most important fruit crops of the world. It has nutritional, medicinal, industrial as well as aesthetic value in Hindu religion. Out of the large number of varieties grown in India, Grand Naine is the popular variety grown mostly in all export oriented countries of Asia, South America and Africa. It is a superior selection of Giant Cavendish which was introduced to India in 1990's. Due to many desirable traits like excellent fruit quality, immunity to fusarium wilt etc, it has proved as a better variety [1]. The quality attributes of ripe fruit are mainly influenced by the genotype, the nutritional status of the soil also plays a significant role [2]. Continuous use of inorganic fertilizers as source of nutrient in imbalanced proportion is also a problem, causing inefficiency, damage to the environment and in certain situations, harms the plants themselves and also to human being who consumes them. Some studies have suggested that organic manures gave better quality and post-harvest life of fruits when comparing to inorganic sources of nutrients in banana [3]. Many investigators studied the combined application of organic manures and amendments can enhance the yield, quality and post-harvest attributes of fruit crops Patel et al. [4] in banana and Akash Sharma et al., [5] in Guava. Organic manures contain macro and micronutrients, plant growth promoting substances like auxins, gibberellins, and cytokinins [6]. However, information regarding the type of organic manure, their optimum dose, and their interaction with bio fertilizers on different quality attributes and shelf life of banana is sketchy. With this background the present study was conducted to determine the impact of different doses of organic manures, amendments and their combinations on important quality attributes and post-harvest life of banana.

\section{Materials and Methods}

The present investigation was carried out at Horticultural College and Research Institute, TNAU, Coimbatore, during the year 2010-11 with banana (Musa spp.) cv. Grand Naine (AAA). The experiment was laid out in a Randomized Block Design with twelve treatments and four replications. The treatments comprised of organic manures, amendments and green manures viz., FYM @ $10 \mathrm{~kg} / \mathrm{plant}+$ Neem Cake@1.25 kg/plant + Vermicompost @ 5 kg/plant and Wood ash @ $1.75 \mathrm{~kg} /$ plant $\left(\mathrm{T}_{1}\right)$, FYM @ $10 \mathrm{~kg} /$ plant + Neem Cake@ @ $1.25 \mathrm{~kg} / \mathrm{plant}+$ Vermicompost@ $5 \mathrm{~kg} /$ plant and Wood ash@ $3.75 \mathrm{~kg} /$ plant $\left(\mathrm{T}_{2}\right)$, FYM @ 15 kg/plant + Neem Cake @ 1.875 kg/plant + Vermicompost @ 7.5 kg/plant and Wood ash @ 625 g/plant $\left(\mathrm{T}_{3}\right)$, FYM @ 15 kg/plant + Neem Cake@ 1.875 kg/plant + Vermicompost @ 7.5 kg/plant and Wood ash@2.625 kg/plant $\left(\mathrm{T}_{4}\right)$, Control - absence of organic and inorganic sources $\left(\mathrm{T}_{5}\right)$, Triple green manuring with sunhemp + Cow pea + Cow pea as inter - crop $\left(\mathrm{T}_{6}\right)$, Arbuscular Mycorrhizae @ $25 \mathrm{~g} /$ plant+Azospirillum @50 g/plant + PSB @ $50 \mathrm{~g}$ and Trichoderma harzianum @ $50 \mathrm{~g} /$ plant $\left(\mathrm{T}_{7}\right), \mathrm{T}_{1}+\mathrm{T}_{6}\left(\mathrm{~T}_{8}\right), \mathrm{T}_{1}+\mathrm{T}_{7}\left(\mathrm{~T}_{9}\right), \mathrm{T}_{1}+\mathrm{T}_{6}+\mathrm{T}_{7}$ $\left(\mathrm{T}_{10}\right)$ and the absolute control treatments (inorganic) $300: 100: 300 \mathrm{~g}$ NPK / plant $\left(\mathrm{T}_{11}\right), 110: 35: 330 \mathrm{~g}$ NPK / plant $\left(\mathrm{T}_{12}\right)$.

The recommended spacing of $1.8 \mathrm{~m} \times 1.8 \mathrm{~m}$ was adopted for planting of banana cv. Grand Naine obtained from organic field. Among the twelve treatments, ten treatments were organic treatments 
Citation: Vanilarasu K and Balakrishnamurthy G (2014) Effect of Organic Manures and Amendments on Quality Attributes and Shelf Life of Banana cv. Grand Naine. Agrotechnol 3: 1000119. doi:10.4172/2168-9881.1000119

Page 2 of 3

(Nutrients equal to the recommended dose of inorganic fertilizers) supplied through organic manures and amendments (FYM and Neem Cake were applied as basal dose, Vermicompost, Vesicular arbuscular mycorrhizae, Azospirllium, Phosphate solubilizing bacteria and Trichoderma harzianum were applied after three month of planting and Wood ash was applied after five month of planting) and rest of them were inorganic treatments with three levels of inorganic fertilizers were applied at 3rd, 5th and 7th month after planting of suckers. Drip irrigation was provided to the experimental plots depending on soil moisture availability. Recommended cultural practices (except nutrient management) and plant protection measures were carried out regularly.

\section{Estimation of important quality traits}

Fully matured representative fingers were allowed for natural and uniform ripening. These fruits were subjected for determining the quality biochemical parameters. The total soluble solids were determined by using Carl-Zeiss hand refractrometer and expressed in per cent. Titrable acidity was estimated by adopting the method of A.O.A.C [7]. (1960) by titrating against $\mathrm{N} / 10 \mathrm{KOH}$ using phenolphthalein indicator and expressed in terms of percentage of citric acid. Ascorbic acid content was estimated using 2,6dichlorophenol indophenol dye and expressed as milligrams of ascorbic acid 100 g-1 [8]. Total, reducing and non-reducing sugars were estimated as per the method suggested by Somogyi [9].

\section{Estimation of post-harvest characteristics}

Shelf life of the fruit was estimated by days taken for the fruits to loose their edible quality as evident by over softening and onset of decay was taken and expressed in number of days. Physiological Loss in Weight (PLW) was assessed by taken Initial weight of the fruits in different treatments were recorded and the final weight was taken as and when the fruits reached the stage of yellow flecked with brown, in each treatment. Physiological loss in weight of fruits was computed at the end of full ripening stage by weight/weight basis by adopting the following formula and the value expressed in percentage.

$$
P L W=\frac{\text { initial weight }- \text { weight after storage }}{\text { initial weight }} \times 100
$$

\section{Results and Discussion}

\section{Effect of different organic manures and amendments on quality of banana}

The fruit quality parameters like TSS (23.23\%), total sugars and non-reducing sugars (14.92\% and 6.06) and ascorbic acid (12.92 mg. $100 \mathrm{~g} \mathrm{-1)}$ contents were registered highest values in plants treated with organic amendments as compared to the inorganic treatments (Table 1), due to the better role of nutrients which is involved in the carbohydrate synthesis, breakdown and translocation of starch, synthesis of protein and neutralization of physiologically important organic acids. These findings are in concordance with the results of Anon [10] in Sapota, Anon [11] in custard apple; Pereira and Mitra [12] in guava and Athani and Hulamni [13] in banana and reported that the increased fruit quality parameters are due to the addition of different organic manures and amendments to the soil and in turn to plants, which might had enhanced the biosynthesis and translocation of carbohydrates in to fruits. Further, the availability of nitrogen from different sources might have increased leaf area with higher synthesis of assimilates which is due to enhanced rate of photosynthesis. Such effects have been attributed to increase rate of translocation of photosynthetic products from leaves to developing fruits and thereby increasing total sugars [14-17].

\begin{tabular}{|c|c|c|c|c|c|c|c|c|}
\hline Treatments & $\begin{array}{l}\text { TSS } \\
(\%)\end{array}$ & Acidity (\%) & $\begin{array}{l}\text { Ascorbic acid (mg. } \\
100 \mathrm{~g} \mathrm{-1})\end{array}$ & $\begin{array}{l}\text { Non-reducing } \\
\text { sugars (\%) }\end{array}$ & $\begin{array}{l}\text { Reducing sugars } \\
(\%)\end{array}$ & Total sugars (\%) & PLW (\%) & $\begin{array}{l}\text { Shelf life } \\
\text { (days) }\end{array}$ \\
\hline T1 & 21.49 & 0.83 & 12.04 & 5.36 & 9.08 & 14.44 & 9.64 & 13.18 \\
\hline T2 & 21.83 & 0.84 & 11.56 & 5.51 & 8.69 & 14.20 & 9.32 & 12.74 \\
\hline T3 & 21.89 & 0.82 & 12.43 & 5.85 & 8.90 & 14.75 & 9.45 & 12.97 \\
\hline T4 & 21.58 & 0.84 & 12.37 & 5.82 & 8.72 & 14.54 & 10.37 & 13.84 \\
\hline T5 & 20.56 & 0.84 & 11.06 & 4.45 & 7.03 & 11.48 & 12.05 & 9.73 \\
\hline T6 & 21.45 & 0.84 & 11.96 & 5.25 & 7.63 & 12.88 & 13.22 & 11.07 \\
\hline $\mathrm{T} 7$ & 21.72 & 0.83 & 12.65 & 5.66 & 8.23 & 13.89 & 8.85 & 13.27 \\
\hline T8 & 21.63 & 0.83 & 12.24 & 5.73 & 7.93 & 13.66 & 9.36 & 13.93 \\
\hline T9 & 22.47 & 0.84 & 12.46 & 5.95 & 9.10 & 15.05 & 7.84 & 13.87 \\
\hline T10 & 23.23 & 0.82 & 12.92 & 6.06 & 8.86 & 14.92 & 7.44 & 14.03 \\
\hline T11 & 21.93 & 0.83 & 11.91 & 5.15 & 8.41 & 13.56 & 11.84 & 10.26 \\
\hline T12 & 22.08 & 0.84 & 12.33 & 5.45 & 8.37 & 13.82 & 11.28 & 10.87 \\
\hline SEd & 0.24 & NS & 0.14 & 0.06 & 0.07 & 0.19 & 0.14 & 0.14 \\
\hline
\end{tabular}


Citation: Vanilarasu K and Balakrishnamurthy G (2014) Effect of Organic Manures and Amendments on Quality Attributes and Shelf Life of Banana cv. Grand Naine. Agrotechnol 3: 1000119. doi:10.4172/2168-9881.1000119

Page 3 of 3

\begin{tabular}{|l|l|l|l|l|l|l|l|l|}
\hline $\mathrm{CD}(0.05)$ & 0.49 & NS & 0.29 & 0.12 & 0.14 & 0.40 & 0.29 & 0.28 \\
\hline
\end{tabular}

Table 1: Effect of organic manures and amendments on quality and post harvest characteristics of banana cv. Grand Naine

\section{Effect different organic manures and amendments on post- harvest characters of banana}

Shelf life of banana is an important parameter and influenced directly by the pre harvest nutritional status of the fruits. The influence of nutrients derived from organic sources had a positive effect on the post-harvest characters of banana (Table 1), the highest shelf life (14.03 days) of fruits and least physiological loss in weight (7.44 per cent) were observed in the treatment $\mathrm{T}_{10}$. On the other hand, the shelf life of the fruits was minimum (9.73 days) and physiological loss in weight was maximum in $\mathrm{T}_{5}$ (12.05 per cent) next to $\mathrm{T}_{6}(13.23$ per cent). The extended shelf life observed in the present study might be due to the consequence of reduced weight loss and other physiological process like reduced respiration and transpiration. This result lends support to the findings of Athani and Hulamni [13] in banana.

\section{Conclusion}

Substitution of organic manures and amendments (biofertilizers and biocontrol agents) and green manures combination significantly enhanced the important quality attributes and post-harvest life of banana compared to either organic manure alone or inorganic sources alone.

\section{References}

1. Singh HP, Chundawat BS (2002) Improved technology of banana Ministry of Agriculture, Government of India: 1-46.

2. Roy SK, Chakroborty AK, MacRae RM, Robinso RK, Sandler MJ (1993) Vegetables of tropical climate-commercial and dietary importance, Encyclopaedia of Food Science. J. Food Technology and Nutrition, Academic press, London.

3. Patel PS, Kolambe BN, Patel HM, Patel TU (2010) Quality of banana as influence by organic farming. Int. J. Bioscience Reporter 8: 175-176.

4. Patel KM, Patel HC, Patel KA, Chauhan VB, Patel JS (2012) Effect of organic manures or chemical fertilizers on yield and quality of banana fruits. The Asian Journal of Horticulture 7: 420-422.
5. Akash Sharma VK, Wali P, Bakshi A, Jasrotia, Sardar CV (2013) Effect of organic and inorganic fertilizers on quality and shelf life of guava (psidium guajava). The Bioscan 8: 1247-1250.

6. Krishnamoorthy RV, Vajrabhiah SN (1986) Biological activity of earthworm casts: an assessment of plant growth promoter levels in casts. Proceedings of the Indian Academy of Science (Animal Sci) 95: 341-351.

7. AOAC (1960) Official Methods of Analysis. Published by AOAC Washington, D.C.

8. Freed M (1966) Methods of Vitamin Assay. Inter science Pub. Inc, New York.

9. Somogyi M (1952) Notes on sugar determination. J. Biol. Chem 195: 19-23.

10. Anonymus (2000) 35th Meeting of Horticulture and Forestry SubCommittee of Agricultural Research Council of GAU, Navsari: 479.

11. Anonymus (2001) 36th Meeting of Horticulture and Forestry SubCommittee of Agricultural Research Council of GAU, Navsari: 67-68.

12. Pereira LS, Mitra SK (1999) Studies on organic along with inorganic nutrition in guava. Indian J Agric 43: 155-160.

13. Athani SI, Hulamani NC (2000) Effect of vermicompost on fruit yield and quality of banana cv. Rajapuri (Musa AAB), Karnataka. J. Agric. Sci 13: $942-946$.

14. Dey P, Rai M, Nath V, Das B, Reddy N (2005) Effect of biofertilizer on physico-chemical characteristics of guava (Psidium guajava L.) fruit. Indian Journal of Agricultural Sciences 75: 95-96.

15. Kaniszewski S, Elkner K (1988) The effect of irrigation and nitrogen fertilization on the yield and quality of direct sown tomatoes. Biuletyn Warzywniczy 32: 29-52.

16. Katyal JC (1989) Fertilizer use and impact on environment. FAI Seminar, New Delhi. Fertilizer, agriculture and national economy 6: 1-8.

17. Kumaran SS, Natarajan S, Thamburaj S (1998) Effect of inorganic and organic fertilizers on growth and yield of tomato. South Indian Horticulture 46: 203-205. 